\title{
RUSSIAN INDUSTRY IN H1 2016: ZERO DYNAMICS ${ }^{1}$
}

\author{
A.Kaukin, G.Idrisov
}

The trend that first became visible in early 2016 - decline giving way to zero rates of growth - towards the end of $\mathrm{H} 1$ had spread across a majority of segments of the economy's real sector. The lack of a noticeable domestic demand and dependence upon foreign equipment supplies coupled with the persistently low relative income generated by exports of raw materials make it impossible to expect any significant domestic production growth in the nearest future ${ }^{2}$.

In spite of the temporary deterioration of the terms of trade in late 2015 early 2016, no significant decline in the main sectors of Russian industry could be observed over the course of $\mathrm{H} 1$, in contrast to the situation in late $2014^{3}$. Rather, the statistical data for early 2016 indicated that the period of a relatively high output volatility in the real sector was over, possibly to give way to the period of a near-zero growth rate ${ }^{4}$. This change was caused by the absence of additional negative factors - in 2014 these had been the introduction of economic sanctions against Russia and Russia's retaliatory sanctions, the events in Ukraine, and the expectations of further deteriorating terms of trade. Besides, late 2015 was a period of gradual stabilization in the economy and adaptation of businesses to the new realities - among other things, by adjusting their business plans and investment projects.

The currently available Rosstat's data ${ }^{5}$ applied by the Gaidar Institute for the purpose of decomposition and removal of the trend component in its by-sector time series analysis ${ }^{6}$ have provided an answer to the question as to how sustainable the trend that first became visible in Q1 actually is (output stabilization and zero growth rates in the majority of segments of the real sector).

The results of our calculations demonstrate (Fig. 1) that on the whole, the situation in industry over Q2 2016 remained stable, while at the same time a slow decline of the Industrial Production Index (IPI) could be observed (99.5\% in July on March 2016).

Similarly to the situation in Q1, the production indices in different sectors still vary across Russian industry, but their values are becoming increasingly uniform and starting to display zero growth rates (Table 1 and Fig. 2).

Among the sectors that over recent months have been displaying positive growth rates, however small, we may point to mineral extraction; textiles and

1 The authors should like to express their gratitude to Marina Turuntseva and Olga Morgunova for their help in statistical analysis.

2 This paper was originally published in Online Monitoring of Russia's Economic Outlook No.14(32).

3 Russian Economy in 2015. Trends and Outlooks (Issue 37). M., IEP. 2016.

4 A. Kaukin, G. Idrisov. Russian industry in Q1 2016: the onset of stagnation? // Online Monitoring of Russia's Economic Outlook. Trends and Challenges of Socioeconomic Development, No. 7 (25), April 2016.

5 Information on the social and economic situation in Russia, January-July 2016, Rosstat.

6 The trend component was removed by using Demetra software package based on X12ARIMA. 


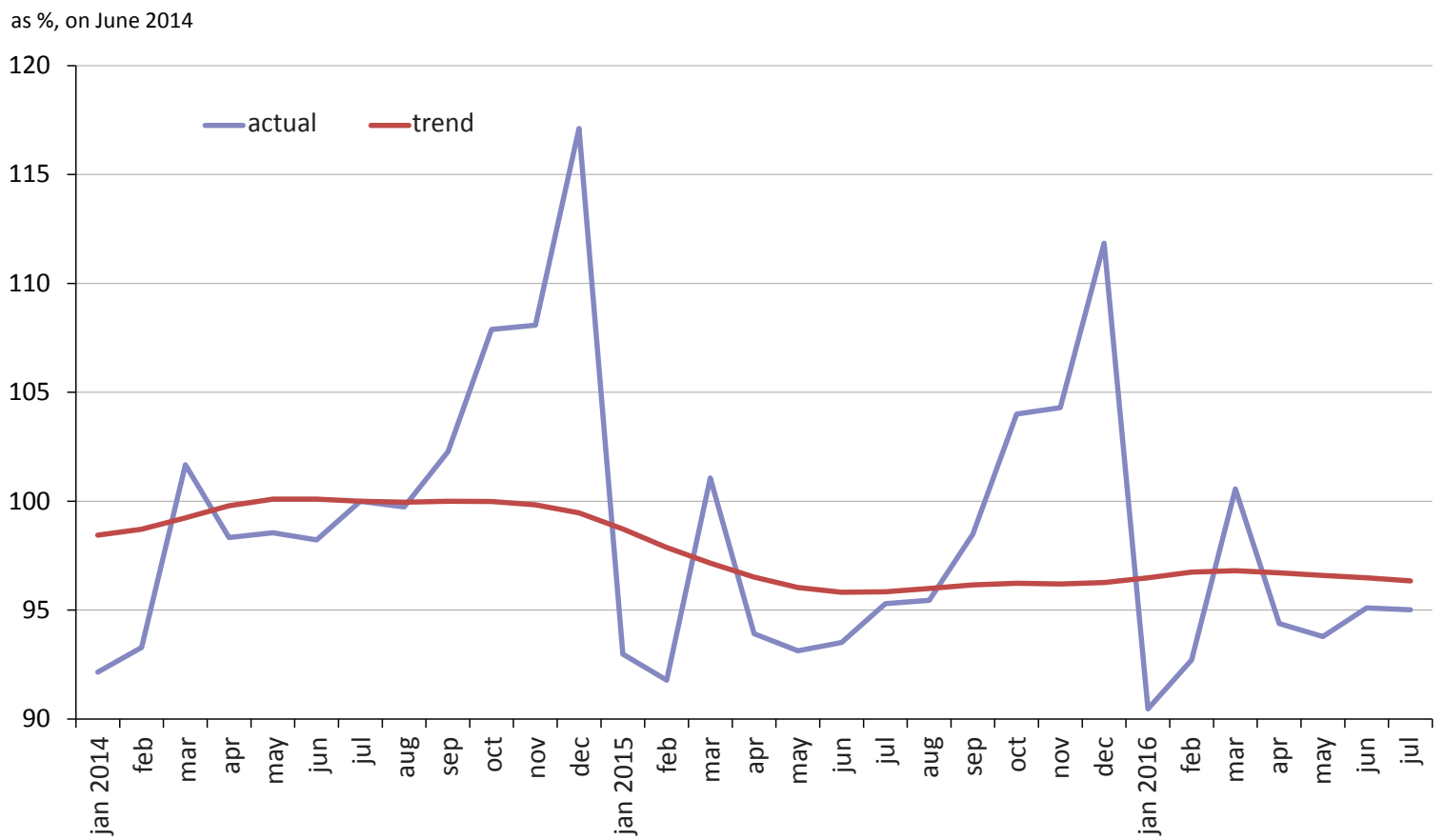

Sources: Rosstat; own calculations.

Fig. 1. The movement of the Industrial Production Index (IPI) in 2014-2016, actual data and trend components

textile products manufacturing; manufacturing of rubber and plastic products; and machinery and equipment manufacturing.

The aftereffects of the 2014 crisis have turned out to be comparatively mild in the manufacturing industry (Fig. 2). Although the implementation of several investment projects was suspended, a certain revival of the investment activity has recently been observed and conduced to slight growth.

The situation in the textiles and textile products manufacturing sector is somewhat more interesting. Traditionally, wages take up a substantial share in the cost structure of textiles and final goods (alongside depreciation and technical upgrading costs). The soaring USD-to-ruble exchange rate after 2014 made the transfer of foreign production entities into Russia's territory ${ }^{1}$ and cooperation of domestic producers with their foreign partners ${ }^{2}$ very attractive; besides, it boosted the demand for Russian exports of these products ${ }^{3}$. In fact, these are examples of inclusion into international value chains, which translates into domestic output growth reflected by an increasing industrial production index in a given sector.

A movement in the opposite direction over the entire period of $\mathrm{H} 12016$ was demonstrated by metallurgical production. The output plunge in that industry, according to experts ${ }^{4}$, was caused primarily by the shrinking domes-

1 SC ELIS will build a new factory in Rostov to the value of Rb 200m // RBC, 18 June 2016. [http://rostov.rbc.ru/rostov/18/07/2016/578ccb5b9a7947109655868c]

2 Pierre Cardin is considering the possibility of clothes manufacturing in the Kuban region // RBC, 23 June 2016. [http://kuban.rbc.ru/krasnodar/23/06/2016/576b89039a79471299fae $7 \mathrm{fb}]$

3 BTKTextile signed contracts forfabric supplies to Italy//RBC, 24 May 2016. [http://rostov.rbc. ru/rostov/freenews/574455a09a7947585491afda]; Recently, we have been observing demand growth // RBC+, 15 June 2016.[http://www.rbcplus.ru/news/575e1dd77a8aa97007fb7e1d] 4 Metallurgical crisis. Problems in Russia // Pro nedra, 3 March 2016. [http://pronedra.ru/ mining/2016/03/03/metallurgicheskiy-krizis-v-rossii/] 
Table 1

THE BY-SECTOR MOVEMENT OF OUTPUT INDICES

\begin{tabular}{|c|c|c|c|c|c|}
\hline & 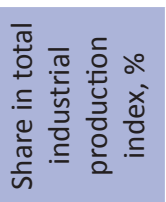 & 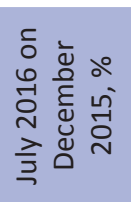 & 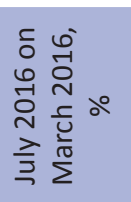 & 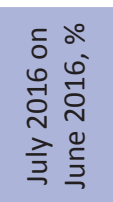 & 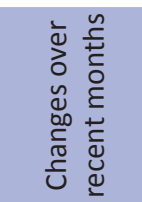 \\
\hline Industrial production index & & 100.09 & 99.52 & 99.86 & stagnation \\
\hline Mineral extraction & 33.99 & 100.25 & 100.37 & 100.26 & $\begin{array}{l}\text { slow } \\
\text { growth }\end{array}$ \\
\hline Manufacturing industry & 52.50 & 99.88 & 99.59 & 99.78 & stagnation \\
\hline \multicolumn{6}{|l|}{ including } \\
\hline $\begin{array}{l}\text { Production of foodstuffs, including beverages, } \\
\text { and tobacco products }\end{array}$ & 17.05 & 100.83 & 100.22 & 100.06 & stagnation \\
\hline Textiles \& textile products manufacturing & 1.43 & 108.48 & 103.25 & 99.84 & $\begin{array}{l}\text { slow } \\
\text { growth }\end{array}$ \\
\hline $\begin{array}{l}\text { Leather production and leather products \& footwear } \\
\text { manufacturing }\end{array}$ & 0.32 & 102.00 & 98.58 & 99.31 & $\begin{array}{l}\text { slow } \\
\text { decline }\end{array}$ \\
\hline Timber \& wood product processing & 2.20 & 100.34 & 99.78 & 99.20 & stagnation \\
\hline Cellulose \& paper production & 3.92 & 100.76 & 99.78 & 99.79 & stagnation \\
\hline Production of coke \& petroleum products & 18.78 & 99.38 & 99.75 & 100.05 & stagnation \\
\hline Chemical production & 7.46 & 100.55 & 99.10 & 99.60 & decline \\
\hline Manufacturing of rubber \& plastic products & 2.26 & 104.10 & 103.49 & 100.00 & growth \\
\hline $\begin{array}{l}\text { Manufacturing of other non-metallic mineral } \\
\text { products }\end{array}$ & 4.41 & 96.07 & 98.87 & 98.96 & $\begin{array}{c}\text { slow } \\
\text { decline }\end{array}$ \\
\hline Metallurgical production \& finished metal products & 17.23 & 97.95 & 97.05 & 98.91 & decline \\
\hline Machinery \& equipment manufacturing & 6.24 & 98.71 & 99.43 & 100.94 & $\begin{array}{l}\text { slow } \\
\text { growth }\end{array}$ \\
\hline $\begin{array}{l}\text { Electrical, electronic and optical equipment } \\
\text { manufacturing }\end{array}$ & 6.05 & 97.81 & 98.54 & 99.63 & decline \\
\hline $\begin{array}{l}\text { Production of means of transport and } \\
\text { transportation equipment }\end{array}$ & 7.06 & 99.35 & 99.24 & 99.41 & decline \\
\hline Other industries & 5.59 & 91.09 & 94.63 & 98.32 & decline \\
\hline Electricity, natural gas \& water & 13.51 & 99.97 & 100.00 & 100.00 & stagnation \\
\hline Retail trade & & 97.37 & 98.58 & 99.75 & decline \\
\hline Wholesale trade* & & 100.43 & 99.31 & 99.75 & stagnation \\
\hline Transport & & 99.70 & 100.65 & 100.49 & $\begin{array}{l}\text { slow } \\
\text { growth }\end{array}$ \\
\hline Construction & & 96.97 & 98.16 & 99.78 & decline \\
\hline Commercial services rendered to population* & & 99.60 & 99.52 & 99.77 & $\begin{array}{l}\text { slow } \\
\text { decline }\end{array}$ \\
\hline
\end{tabular}

* for these sectors, calculations were done as of June 2016.

Sources: Rosstat; own calculations.

tic demand (a declining construction volume coupled with a general industrial production decline), as well as by the introduction of antidumping duties and economic sanctions by the European Union ${ }^{1}$, which prevented Russian metallurgists from taking advantage of their new competitive opportunities that had arisen as a result of the shrinking ruble-denominated component of their costs in the final price of their products (denominated in US dollars) after the ruble's weakening (as it happened in the case of textiles and textile products manufacturing).

1 Russian metallurgists have come under the European Union's sanctions // RBC, 4 August 2016. [http://www.rbc.ru/business/04/08/2016/57a311779a79475ea5c2fd91] 
Mineral extraction
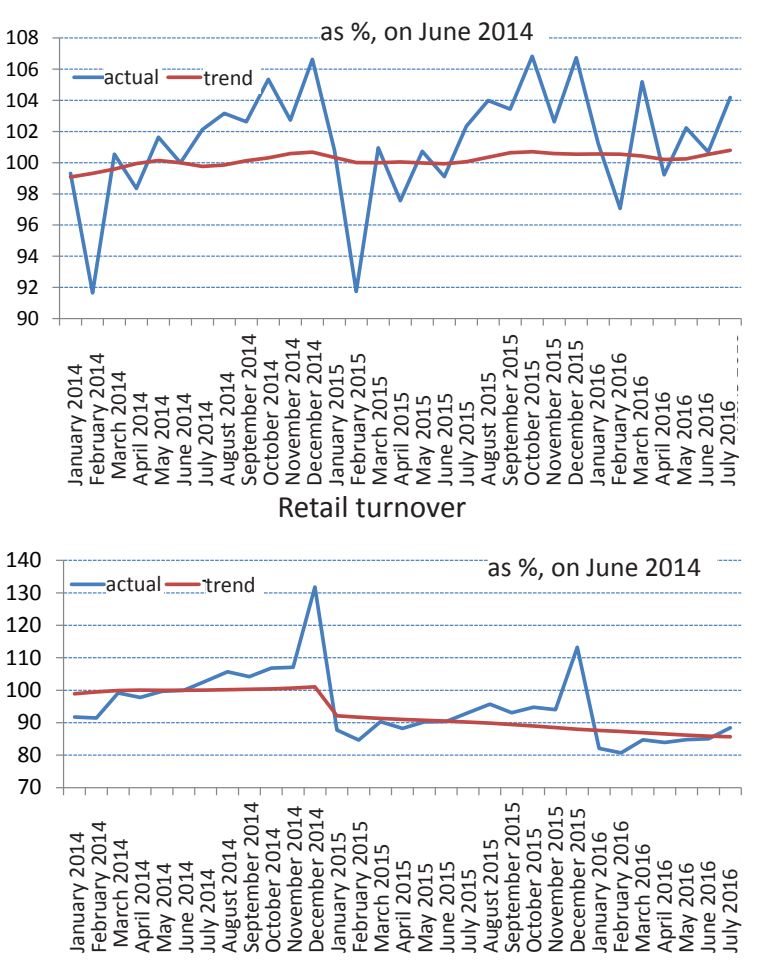

Freight turnover

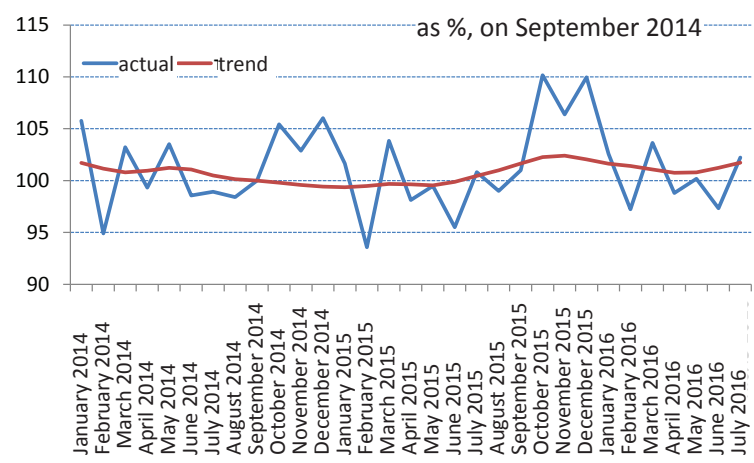

Manufacturing industry
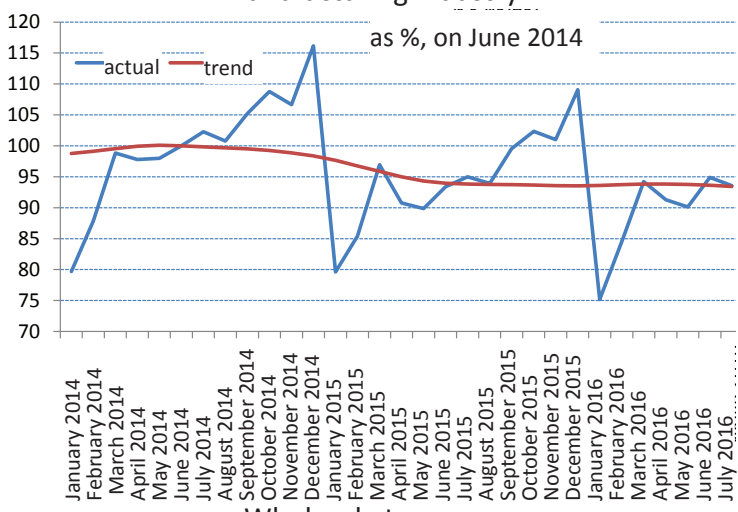
Wholesale turnover
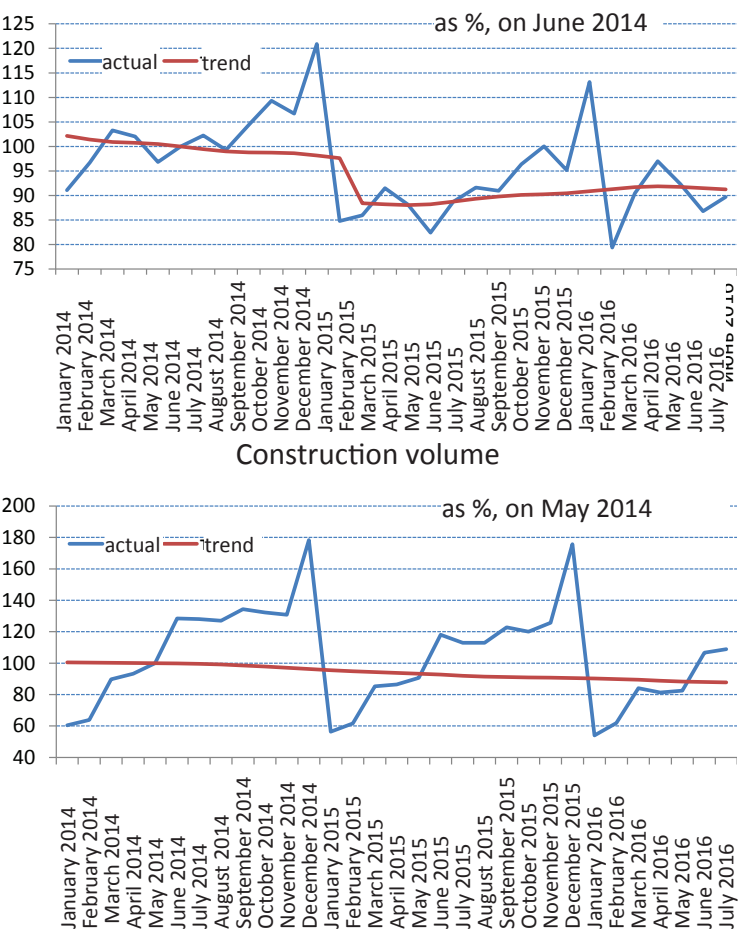

Sources: Rosstat; own calculations.

Fig. 2. The by-sector movement of production indices in 2014-2016, actual data and trend components

On the whole in the machinery and equipment manufacturing sectors, including the production of electrical and transportation equipment, output continues its decline caused both by the general shrinkage of demand for their products and their rather high dependence on foreign equipment and spare parts, which have become significantly more expensive due to the ruble's plunge. Slight output growth over recent months has been observed only in the machinery and equipment manufacturing sector, but this is obviously only a manifestation of recovery growth ${ }^{1}$. The government support measures for the production of means of transport and transportation equipment ${ }^{2}$ have not yielded any results as yet, judging by the movement of the production indices.

1 Some branches of the Russian economy are entering the new year with optimism // Vzglyad, 5 January 2016. [http://vz.ru/economy/2016/1/5/786502.html]

2 Program of transport machine-building for 2016 (Directive of the Government of the Russian Federation of 21 January 2016, No. 57-r). 
Other important sectors have been displaying practically no growth: the decline in the retail and construction sectors is continuing; the wholesale sector is stagnating; and slight growth can be observed only in freight turnover (Table 1 and Fig. 2). 